\title{
PECULIARITIES OF PROFESSIONAL SELF-ATTITUDE FORMATION AT FUTURE SOCIAL WORKERS DURING THEIR UNIVERSITY TRAINING
}

\author{
Zhanna Melnik ${ }^{1}$, Dmytro Spivak ${ }^{2}$ \\ ${ }^{1}$ Ph.D. in Psychology, Associate Professor at the Department of Social Pedagogic and \\ Social Work, Ivan Ohiienko National University in Kamianets-Podilskyi, Kamianets-Podilskyi \\ (Ukraine) \\ ORCID ID: https://orcid.org/0000-0003-3348-0939 \\ ${ }^{2}$ Postgraduate Student at the Department of Social Pedagogic and Social Work, Ivan \\ Ohiienko National University in Kamianets-Podilskyi, Kamianets-Podilskyi (Ukraine) \\ ORCID ID: https://orcid.org/0000-0002-2801-7803
}

UDC: 159.923 .2

\begin{abstract}
The article presents the results of the empirical study on future social workers' professional selfattitudes during their studying at university. The essence of the "future social workers' professional self-attitudes" phenomenon is presented, which is shown in their experiences regarding to their own professionally important qualities and competences. We determined the positive but insufficient dynamics of the professional self-attitude development at future social workers -"bachelor" degree students of the first-fourth academic years during their professional training at university. There are large statistically significant increase of the number of students with high professional self-attitudes, statistically significant decrease of the number of students with average professional self-attitudes and insignificant decrease of the number of with low professional self-attitudes from the first to the fourth academic year. The obtained results are important for elaboration of effective psychological support for future social workers' professional "Self-concept" development, in general, and their professional self-attitude, in particular, during their professional training.
\end{abstract}

Keywords: professional self-attitude, development, future social workers, students, higher education institutions.

Address for correspondence, e-mail : editpsychas@gmail.com

Copyright: (C) Zhanna Melnik, Dmytro Spivak

This is an Open Access journal, all articles are distributed under the terms of the Creative Commons AttributionNonCommercial-ShareAlike 4.0 International (CC BY-NC-SA 4.0) License (http://creativecommons.org/licenses/by-nc$\mathrm{sa} / 4.0 /$ ), allowing third parties to copy and redistribute the material in any medium or format and to remix, transform, and build upon the material, provided the original work is properly cited and states its license. 


\section{Introduction}

The continuous processes in Ukraine aimed at its entrance to the European area and the corresponding socio-political and socio-economic transformations determine the increased need for social services to certain categories of Ukrainian citizens. The state law of Ukraine "On social services" declares that social workers are to carry out psychological, rehabilitative and other activities to improve or restore lives of those people who are needed professional help. The Laws of Ukraine "On Education" and "On Higher Education" emphasize the importance of highly qualified specialists with harmonious professional self -concept. Therefore, the important task of modern Ukrainian psychological science and practice is to study the components of future social workers' professional self-concept and to propose the effective psychological support during their professional training.

Analysis of recent researches and publications

The analysed latest scientific psychological researches and publications of Ukrainian scientists show studies concerning certain professional "Self-concept" components of future specialists in the social work sphere.

O.P. Patinok convincingly proves the influence of self-attitude stability on the development of future social workers' responsibility during their university training. The psychologist empirically recorded increased responsibility of students, as future specialists in the social work sphere, during their professional training. For the fourth academic year, the number of highly responsible students is reached of half of all examined future social workers. The author also empirically defined that, apart from self-attitude, significant influence on the future professionals' responsibility during their university training have such psychological factors as their ability to subjective control and professional orientation (Patinok, 2008).

Thus, the subject of O.P. Patinok' scientific study was the psychological factors influencing the future social workers' responsibility development during their professional training. Responsibility is one of the important factors of future social workers' self-assessment, which is at the same time an important component of their professional self-concept.

The main psychological factors influencing development of future social workers' selfconcept were empirically determined in the research of N.M. Bamburak. The psychologist found that during professional studying at university, students intensively develop their positive communicative attitudes, social and psychological orientation and subjective control. However, to the end of professional training, not all future social workers showed average, high or very high development levels of mentioned mental formations. In the view of the obtained results, a comprehensive technology for future social workers' self-concept development during their pro- 
fessional training was developed and its effectiveness was confirmed (Bamburak, 2010).

Thus, N.M. Bamburak studied some psychological factors of future social workers' selfconcept development during their professional university training. Namely, they are: communicative attitudes, socio-psychological orientations and subjective control.

The empirical study on the developmental dynamics of future social workers' personal competence during vocational studying is described in the scientific work of M.D. Lapina. According to the scientists, social workers' personal competence consists of the operational, motivationalvalue and reflexive components. The operational component represented by social workers' communicative competence, stress resistance, ability to self-control and self-organization. The motivational-value component contains social workers' empathy and tolerance. The reflective component includes reflexivity, professional reflection. At different stages of professional training, high empathy, average tolerance and ability to organize themselves, low communicative and organizational qualities and stress resistance, as well as low reflexivity of future social workers were found (Lapina, 2017).

It should be noted that M.D. Lapina explores the developmental dynamics of future social workers' ability to self-control and selforganization and reflection. However, the scientist does not studied the developmental dynamics of other constructs of future social workers' pro- fessional self-concept and the corresponding psychological mechanisms.

In general, the performed theoretical analysis shows that modern Ukrainian scientists in psychology explore only certain aspects of future social workers' professional self-awareness and their self-concept. The question of the developmental dynamics of future social workers' professional self-attitudes during their professional university training remains beyond their scientific interests.

The research aim was to define empirically the dynamics of future social workers' professional self-attitudes during their professional university training.

The goal was achieved by fulfilment of the following tasks: 1) the definition of the essence of "professional self-attitude"; 2) the empirical study of the dynamics of future social workers' professional self-attitudes; the firstfourth academic year students obtaining the "bachelor" degree participated at this study.

Scientific substantiation of the research methodology. According to the scientific views (Borysiuk, 2011; Kalamazh, 2010; Kokun, 2012), which we agree with, future social workers' professional self-concept is a complex integrated formation that include their own understanding of professionally relevant personal qualities and competences, assessment of such qualities, value attitude to them, and corresponding behaviour. Future social workers' professional self-attitude 
is an important component of their professional self-concept, which presents their feelings about own professionally important qualities and competences.

The questionnaire "Attitude towards oneself as a professional" (Borysiuk, 2011) was used to achieve the research goal and to solve corresponding tasks and to reveal the dynamics of future social workers' professional self-attitude during their professional university training. We determined the integral indicator of future social workers' professional self-attitudes with this questionnaire. This integral indicator is constructed from the following partial indicators: an expected attitude from others to an individual as a professional, sympathy for oneself as a professional, respect for oneself as a professional, selfconsistency as a professional, understanding oneself as a professional, acceptance of oneself as a professional, professional self-esteem, selfcontrol, uncertainty of oneself as a professional, self-blame as a professional.

For the mathematical and statistical processing of the obtained results, the F-test with angular transformation was used. The value $\varphi^{*}$ of F-test at $\mathrm{p} \leq 0.01$ is marked by $*$, at $\mathrm{p} \leq 0.05$ is done by $* *$.

The empirical study of the dynamics of future social workers' professional self-attitudes was organised on the basis of universities in the cities of Kyiv, Kamianets-Podilskyi, Rivne and Berdyansk during the 2017-2018 academic year. The study involved 311 first-fourth-year students.
Of these, there were 76 first-year students, 88 second-year students, 75 third-year students, 72 fourth-year students of the bachelor's degree in Social Work. Age of students was from 17 to 23 years.

The main research material with full substantiation of scientific results. The obtained results on the dynamics of the integral professional self-attitude indicator for the students-future social workers are presented in Figure 1.

As Figure 1 show that, in general, the professional self-attitudes of the most future social workers are average or high, the low level was shown only the smallest part of the students. From the first to the fourth year of professional training, there are statistically significant increase of the students with high professional self-attitude and simultaneous decrease of the students with average one. The differences between the data obtained for the first-year students' self-attitudes and those of fourth-year students are statistically significant for the high $\left(\varphi^{*}=5.083^{*}\right)$ and the av-

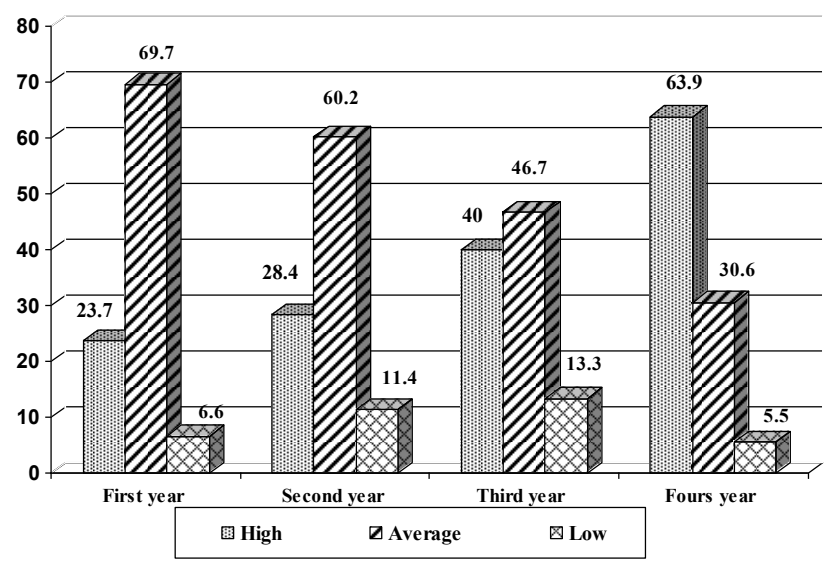

Figure 1. The integral professional self-attitude indicator of the 1-4 academic year students in Social Work $(\%), n=311$ 
erage levels $\left(\varphi^{*}=4.889^{*}\right)$. There are no statistically significant differences between the data of the first academic-year students and the fourth academic-year students showed low professional self-attitudes $(\varphi *=0.255)$.

However, the comparison of high-, average- and low-level data between students of each previous and next academic year showed different patterns. Let us examine these statistical differences for the integral professional self-attitude indicator in more details.

$23.7 \%$ of the first-year students, $28.4 \%$ of the second-year students, $40 \%$ of the third-year students, $63.9 \%$ of the fourth-year students have high professional self-attitudes. For the high professional self-attitude, there are no statistically significant differences between the data of the first and second year students $\left(\varphi^{*}=0.638\right)$ and the second and third year students $\left(\varphi^{*}=1.559\right)$. But, the differences between the data of the third and fourth academic year students $\left(\varphi^{*}=2.933^{*}\right)$ are statistically significant.

The students with high professional selfattitudes perceive professional qualities of social workers as characteristic for them and they are very interested in their own professional "Self". Their professional self-esteem and self-respect are high. They estimate themselves as professionals highly enough. In addition, the future social workers believe that significant others also rate them as highly skilled people. According to these students, they do not need to change their professional skills too much. According to them, their highest professionalism is facilitated by their energy, willpower and commitment.

The average professional self-attitudes were shown by $69.7 \%$ of the first year students, $60.2 \%$ of the second year students, $46.7 \%$ of the third year students, $30.6 \%$ of the fourth year students. For the average professional self-attitude, there are no statistically significant differences between the data of the first and second academic year students $\left(\varphi^{*}=1.277\right)$. But, there are statistically significant differences between the data shown by the second and third year students $\left(\varphi^{*}\right.$ $=1.724^{* *}$ ) and between the data shown by the third and fourth year students $\left(\varphi^{*}=2.018^{* *}\right)$.

The students with average professional self-attitudes agree that professional qualities of social workers as characteristic for them to some extent. Their professional self is sufficiently interesting to them. These future social workers often emphasize their interest in their professional self, but their professional self-esteem and self -respect are not high enough. These students are convinced that significant others evaluate them as professionals likewise. They agree that their professional development should be partially changed. In their opinion, the achievement of high professionalism by them is hampered by lack of energy, insufficient development of volitional qualities and purposefulness.

The low professional self-attitudes were determined at $6.6 \%$ of the first year students, 
$11.4 \%$ of the second year students, $13.3 \%$ of the third year students, $5.5 \%$ of the fourth year students. For the low professional self-attitude, there are no statistically significant differences between the data of the students from all academic years $\left(\varphi^{*}=1.079\right)$, between the second and third year students $\left(\varphi^{*}=0.369\right)$, the third and fourth year students $\left(\varphi^{*}=1.63\right)$.

The students with low professional selfattitudes are uncertain that that have professional qualities necessary for social workers. Professional self-esteem and self-respect of these students is below average. The students with low professional self-attitude believe that significant others also rate their professional qualities below average. They are often convinced that if a wise person were able to "see them through" then that person would immediately understand their worthlessness as professionals. They do not give too much interest to their professional self. Such students have a poor understanding of the essence of their professional role.

Summarizing the obtained data, we emphasize the positive, albeit insufficient, dynamics of future social workers' professional self-attitude development of during their professional university training. The determined changes are explained by the peculiarities of future social workers' professional formation during each year of their professional training.

Thus, during the first year of professional training, students gain more knowledge in general science disciplines and less knowledge in profes- sional educational disciplines, professional orientation. In addition, the changes revealed during the first year of training are explained by the low level of significance and relevance for the students of their professional identity as social workers. That is why their professional self-esteem is low also. This fact was empirically determined by us earlier and presented in our previous scientific articles (Spivak, 2016, 2018).

During the second academic year, the number of professional disciplines learned by students increases. The changes determined for the second academic can be in addition explained by the increased importance and relevance for the students of their professional identity as social workers. Apart from this, we identified more early increased professional self-esteem of the second-year students, which was highlighted in our previous scientific publications (Spivak, 2016, 2018).

During the third, and especially the fourth, academic years, the number of specialised disciplines rises significantly and the students' professional practice as social workers becomes mandatory. During the third and fourth academic years, significance and relevance of professional identity and professional self-esteem rise very sharply. This fact was revealed in our previous research (Spivak, 2016, 2018).

The positive impact of the specialised disciplines on future social workers - students of Ukrainian universities, on their social activities as an important professional competence was empir- 
ically determined and is discussed in modern scientific works of national psychologists (Lyovochkina, Lyuta, 2018).

Conclusions. The empirical study allows us to formulate the following conclusions. The professional attitude of future social workers reflects their experiences regarding their own professionally important qualities and competences that are developed during professional training. During professional university training of future social workers, there are large statistically significant increase of the number of the students with high professional self-attitudes, statistically significant decrease of the students with average professional self-attitudes and insignificant decrease of the students with low professional selfattitudes from the first to the fourth academic year.

The positive, but insufficient, dynamics of professional self-attitude development revealed at future social worker during their professional training at the national universities was defined empirically. The development of future social workers' professional self-attitude is conditioned by assessments of them by significant others, their self-assessments of their own professional qualities, importance and relevance for them of their professional identity.

The prospects of further scientific research are in the development and approbation of psychological techniques supporting basic constructs of future social workers' professional self- concept (professional self-image, professional self-esteem, professional attitudes, professional identity and professional self-regulation) during their professional university training.

\section{References (Transliteration):}

Bamburak, N.M. (2010). Rozvitok Ja-koncepciï osobistosti majbutn'ogo social'nogo pracivnika $\mathrm{u}$ vishhomu navchal'nomu zakladi [Development of a personal's self-concept of future social worker]. Extended $a b$ stract of PhD thesis. Hmel'nic'kij [in Ukrainian].

Borysiuk, A.S. (2011). Sotsialno-psykholohichni zasady stanovlennia profesiinoi identychnosti maibutnoho medychnoho psykholoha [Social and psychological foundations to form professional identity of future medical psychologists]. Extended abstract of doctoral thesis. Ivano-Frankivsk [in Ukrainian].

Kalamazh, R.V. (2010). Psykholohiia formuvannia profesiinoi Ya-kontseptsii maibutnikh yurystiv [Psychology of future layers' professional self-concept formation]. Extended abstract of doctoral thesis. Ostroh [in Ukrainian].

Kokun, O.M. (2012). Psykholohiia profesiinoho stanovlennia suchasnoho fakhivtsia [Psychology of a modern specialist's professional development]. Kyiv: DP «Informatsiino-analitychne ahentstvo»[in Ukrainian].

Lapina, M.D. (2017). Dynamika rozvytku osobystisnoi kompetentnosti sotsialnykh pratsivnykiv $\mathrm{v}$ umovakh profilnoi osvity [The developmental dynamics of social workers' personal competence in the terms of vocational education]. - Psykholohichni perspektyvy, 30, 113-123. [in Ukrainian].

L'ovochkina, A. \& Ljuta, L. (2018). Psihologija formuvann- 
ja social'noï aktivnosti majbutnih social'nih pracivnikiv [Psychology of future social workers' social activity formation]. - Nauka i osvita, 5-6, 3138. [in Ukrainian].

Patinok, O.P. (2008). Stanovlennja vidpovidal'nosti jak profesijno znachushhoï jakosti social'nogo pracivnika [Formation of responsibility as a professionally significant quality of social workers]. Extended $a b$ stract of candidate's thesis. Kyiv [in Ukrainian]

Spivak, D.V. (2018). Dinamika rozvitku profesijnoï samootsinky majbutnih social'nih pracivnikiv [Dynamics of professional self-esteem development at future social workers]. - Problemy suchasnoi psykholohii : zb. nauk. prats DVNZ «Zaporizkyi natsionalnyi universytet» ta Instytutu psykholohii imeni H. S. Kostiuka NAPN Ukrainy / Za red. S. D. Maksymenka, N. F. Shevchenko, M. H. Tkalych, 2 (14), 130-135 [in Ukrainian].

Spivak, D.V. (2016). Dinamika rozvitku profesijnoï identichnosti majbutnih social'nih pracivnikiv [Dynamics of professional identity development at future social workers]. - Naukovi zapiski Natsionalnoho universytetu «Ostroz'ka akademija», 4, 177-187 [in Ukrainian].

\section{Мельник Жанна Василівна}

Кандидат психологічних наук, дочент кафедри соиіальної педагогіки $i$ сочіальної роботи, Кам'янецьПодільський національний університет імені Івана Огієнка, м. Кам'янець-Подільський (Украӥна)

\section{Співак Дмитро Вімалійович}

Аспірант кафедри соиіальної педагогіки $і$ сочіальноі роботи, Кам'янець-Подільський наџіональний університет імені Івана Огієнка, м. Кам'янець-Подільський (Україна)

\section{ОСОБЛИВОСТІ РОЗВИТКУ ПРОФЕСІЙ- НОГО САМОСТАВЛЕННЯ МАЙБУТНІХ СОЦІАЛЬНИХ ПРАЦІВНИКІВ УПРО- ДОВЖ ЇХ НАВЧАННЯ У ЗАКЛАДАХ ВИ- ЩОЇ ОСВІТИ}

Анотація. У статті презентовано результати емпіричного дослідження особливостей розвитку професійного самоставлення майбутніх соціальних працівників упродовж їх навчання у закладах вищої освіти. Розкрито сутність феномена «професійне самоставлення майбутніх соціальних працівників», що презентовано в їх переживаннях щодо власних професійно важливих якостей і компетенцій. Емпірично встановлено позитивну, проте недостатню динаміку розвитку професійного самоставлення майбутніх соціальних працівників, студентів перших-четвертих курсів освітньо-професійного рівня «бакалавр» упродовж їх професійного навчання у вітчизняних закладах вищої освіти. Від першого до четвертого року професійного навчання студентів виявлено значне статистично значуще збільшення кількісних даних високого рівня, статистично значуще зменшення кількісних даних середнього рівня і статистично незначуще зменшення кількісних даних низького рівня професійного самоставлення. Одержані результати є важливими для розробки ефективного психологічного супроводу розвитку професійної «Я-концепції» загалом і професійного самоставлення зокрема у майбутніх соціальних працівників у процесі їх професійного навчання. 
Ключові слова: професійне самоставлення, розвиток, майбутні соціальні працівники, студенти, заклади вищої освіти.

\section{Мельник Жанна Васильевна}

Кандидат психологических наук, доиент кафедры соичиальной педагогики и социальной работы, КаменеиПодольский национальный университет имени Ивана Огиенко, г. Каменеи-Подольский (Украина)

\section{Спивак Дмитрий Витальевич}

Аспирант кафедры сочиальной педагогики и сочиальной работы, Каменеи-Подольский национальный университет имени Ивана Огиенко, 2. КаменеиПодольский (Украина)

\section{ОСОБЕННОСТИ РАЗВИТИЯ ПРОФЕССИОНАЛЬНОГО САМООТНОШЕНИЯ БУДУЩИХ СОЦИАЛЬНЫХ РАБОТНИКОВ В ТЕЧЕНИЕ ИХ ОБУЧЕНИЯ В УЧРЕЖДЕНИЯХ ВЫСШЕГО ОБРАЗОВАНИЯ}

\section{АННОТАЦИЯ}

В статье представлены результаты эмпирического исследования особенностей развития профессионального самоотношения будущих социальных работников в течение их обучения в учреждениях высшего образования. Раскрыта сущность феномена «профессионального самоотношения будущих социальных работников», что представлено в их переживаниях относительно собственных профессионально важных качеств и компетенций. Эмпирически установлено положительную, однако, недостаточную динамику развития профессионального самоотношения будущих социальных работников, студентов пер- вых-четвертых курсов образовательнопрофессионального уровня «бакалавр» в течение их профессионального обучения в отечественных учреждениях высшего образования. От первого до четвертого года профессионального обучения студентов выявлено значительное статистически значимое увеличение количественных данных высокого уровня, статистически значимое уменьшение количественных данных среднего уровня и статистически незначительное уменьшение количественных данных низкого уровня профессионального самоотношения. Полученные результаты важны для разработки эффективного психологического сопровождения развития профессиональной «Я-концепции» в целом и профессионального самоотношения в частности у будущих социальных работников в процессе их профессионального обучения.

Ключевые слова: профессиональное самоотношение, развитие, будущие социальные работники, студенты, высшие учебные заведения. 